\title{
Políticas de Infância / Childhood Policies
}

https://doi.org/10.21814/uminho.ed.36.51

\section{Lourdes Gaitán}

Socia Fundadora do Grupo de Sociología de la Infancia y la Adolescencia (GSIA);

Presidente do Comité Científico de Sociología de la Infancia (FES); Co-directora da Revista SOCIEDAD E INFANCIAS, España 



\section{Políticas de Infância}

Para uma primeira abordagem ao conceito, será útil definir separadamente os dois termos que o formam. Por um lado, o termo "políticas" refere-se ao conjunto de ações que são postas em prática tendo em vista a realização de certos objetivos orientados para o bem comum e aplicados aos membros de uma comunidade humana. A palavra "política" vem do latim e do grego antigo, significando o que está relacionado ao governo da polis. Por outro lado, o termo infância, do ponto de vista sociológico, é aquele período da vida humana (estabelecido, convencionalmente, entre 0 e 17 anos) em que uma pessoa é vista e tratada como criança.

Políticas para a infância poderiam ser definidas, portanto, como aquelas ações voltadas para o governo das crianças e dirigidas para o seu benefício.

Por detrás desta definição simples, surge a complexidade de um campo que engloba múltiplas dimensões que podem ser analisadas sob diversos pontos de vista, como os normativo-jurídicos, organizacionais ou ideológicos, que aqui se tomam como referência.

No plano normativo-legal, a Convenção sobre os Direitos da Criança9 representa o paradigma da ação governamental voltada para a infância, uma vez que os Estados que a ratificaram ${ }^{10}$ se comprometem a garantir o cumprimento dos direitos humanos (direitos civis, sociais e políticos) dos menores de 18 anos, mediante a adoção de medidas (políticas) pertinentes. Convencionalmente, e por razões práticas, os artigos da Convenção foram agrupados em três categorias.

Os direitos de provisão correspondem aos direitos sociais e incluem artigos que reconhecem o direito da criança a gozar do mais alto nível de saúde possível, a um nível de vida adequado ao seu desenvolvimento físico, mental, espiritual, moral e social e a uma educação de qualidade. As ações voltadas para o cumprimento desse conjunto de direitos constituem a finalidade principal das chamadas políticas sociais para as crianças, que

9 Aprovado pela Assembleia Geral das Nações Unidas em 20 de novembro de 1989.

10 Todos os Estados do mundo exceto os Estados Unidos da América. 
também podem incluir benefícios que chegam às crianças por meio das suas famílias (como benefícios fiscais, transferências de dinheiro, creche, habitação) que costumam designar-se como o "pacote de benefícios para as crianças".

Os direitos de proteção incluem todos os artigos da Convenção que se referem explicitamente à obrigação de proteger as crianças de qualquer forma de abuso físico ou mental, tratamento negligente, exploração, tortura, conflitos armados ou atendimento a pessoas com necessidades especiais (como refugiados, deficientes mentais ou físicos, ou pertencentes a minorias étnicas, religiosas, linguísticas ou indígenas). As políticas que se destinam a garantir a proteção dessas situações são reguladas legislativa, administrativamente ou outras, como programas ou serviços especializados.

A categoria dos direitos de participação inclui artigos que visam assegurar que a opinião das crianças seja tida em consideração na tomada de decisões sobre todos os assuntos que as afetem (artigo 12. ${ }^{\circ}$ ), bem como a sua presença ativa na vida social, garantindo para o efeito, o acesso a informação adequada, o direito a se expressar livremente, a reunir-se pacificamente, a constituir associações e a participar na vida cultural da comunidade. Ações concretas podem ser implementadas, neste caso, por meio de várias políticas, sejam elas estabelecidas para toda a população (como as políticas culturais) ou específicas (como a participação infantil).

A nível organizacional, as políticas da infância podem adotar, e fazem-no de facto, fórmulas diferentes:

- Quanto à dimensão: universal (para todas as crianças) / focado (nos grupos mais vulneráveis).

- Quanto à prestação: prestações pecuniárias / serviços de assistência.

- Quanto à equidade:vertical (redistributiva) / horizontal (geracional).

- Quanto ao escopo: local (país) / global (mundo).

- Quanto à gestão: público / privado.

No plano ideológico, as políticas para a infância não se diferenciam da orientação que as políticas públicas em geral seguem. Numa primeira fase, as políticas da infância aplicadas pelos Estados consistiam em medidas de 
proteção jurídica (contra o abuso ou exploração do trabalho) ou medidas de assistência (para a cobertura das necessidades vitais básicas). Após a Segunda Guerra Mundial, com o surgimento do Estado-Providência, as políticas da infância seguiram duas tendências: um sistema de benefícios e serviços universais para todas as classes sociais, ou um conjunto de programas compensatórios para atenuar as deficiências resultantes da escassez de recursos, que legitimam a intervenção em famílias de baixa condição social. Já após o Estado-Providência, a partir da década de 2000, ocorre um deslocamento para políticas menos universalistas e mais voltadas para grupos de alto risco, o que reduz o anterior impulso promocional e redistributivo das políticas infantis. 0 discurso do "investimento na infância" passa a ser dominante, vendo as crianças como uma futura força produtiva, e não como pessoas com direito a uma boa infância.

\section{Childhood Policies}

For a first approach to this concept, it will be useful to define the two terms that form it separately. On the one hand, the term "policies" refers to the set of actions that are put in place for the achievement of certain goals oriented to the common good and applied to the members of a human community. The word "policy" comes from Latin and ancient Greek, meaning that which is related to the polis government. On the other hand, the term childhood, from a sociological point of view, is that period of human life (established, conventionally, between 0 and 17 years of age) in which a person is seen and treated as a child.

Childhood policies could be defined, consequently, as those actions aimed at the government of children and oriented to their benefit.

Behind this simple definition, lies the complexity of a field that encompasses multiple dimensions which can be analysed from different points of view, such as those referring to the normative-legal, organizational or ideological level, which will be used here as a reference.

On a normative-legal level, the Convention on the Rights of the Child ${ }^{11}$ represents the paradigm of government actions aimed at children, since the states that have ratified $\mathrm{it}^{12}$ commit themselves to guaranteeing the fulfilment of human rights (civil, social and political rights) of persons under

11 Approved by the General Assembly of the United Nations, on November 20, 1989.

12 All of the world except the United States of America. 
18 years of age, through the adoption of the relevant (policies) measures. Conventionally, and for practical reasons, the articles of the Convention have been grouped into three blocks.

The provision block corresponds to social rights and includes articles that recognize the right of the child to enjoy the highest possible level of health, an adequate standard of living for their physical, mental, spiritual, moral and social development and a quality education. Actions aimed at complying with this set of rights constitute the main purpose of what are termed social policies for children, which may also include benefits that reach children through their families (such as tax benefits, money transfers, childcare services, housing) that usually make up the "child benefits package".

The protection block includes all the articles of the Convention that explicitly refer to the obligation to protect children from any form of physical or mental abuse, negligent treatment, exploitation, torture, armed conflicts, or to attend to those with special needs (such as refugees, mentally or physically handicapped, or those belonging to ethnic, religious, linguistic or indigenous minorities). The policies applied to guarantee protection in these situations will generally be legislative, administrative or other, such as specialized programs or services.

The participation block includes articles aimed at ensuring that children's opinion is taken into account in the decision-making of all matters affecting them (article 12) as well as their active presence in social life, thus ensuring their access to adequate information, their right to express themselves freely, to hold peaceful meetings, to constitute associations and to participate in the cultural life of their community. Concrete actions can be implemented in this case through various policies, whether they are established in general for the entire population (such as cultural policies) or specifically (such as child participation).

At the organizational level, childhood policies can and do adopt different formulas:

- With regard to the dimension: universal (for all children) / focused (on the most vulnerable groups)

-With regard to the provision: cash benefits / care services. 
- With regard to equity: vertical (redistributive) / horizontal (generational).

-With regard to the scope: local (country) / global (world).

- With regard to management: public / private.

On the ideological level, childhood policies are not only different from, but also quite the opposite of the orientation that public policies in general follow. At an initial stage, the childhood policies that were applied by the States consisted of legal protection measures (against abuse or labour exploitation) or assistance measures (for the coverage of basic vital needs). After World War II, with the emergence of welfare states, childhood policies were able to follow two trends: a system of universal benefits and services for all social classes, or a set of compensatory programs to alleviate the resulting scarcity of resources, which legitimize the intervention in families in certain sectors of the population. Already in the post-welfare stage, starting in the 2000s, there is a shift towards less universal policies and more focus on high-risk groups. This reduces the previous promotional and redistributive impulse of childhood policies. The discourse of "investment in childhood" is now dominant, which sees children as a future productive force, rather than as people with the right to enjoy a good childhood.

\section{Referências / References}

Bradshaw, J. (2007). Child benefits packages in 22 countries. In H. Wintersberger et al. (Eds.), Childhood, Generational Order and the Welfare State: Exploring Children's Social and Economic Welfare (pp. 141-157). Odense: University Press of Southern Denmark.

Gaitán, L. (2006). El bienestar social de la infancia y los derechos de los niños. Política y Sociedad, 43(1), 63-80.

Qvortrup, J. (2010). Infância e política. Cadernos de Pesquisa, 40(141), 777-792. 